\title{
КИЇВСЬКИЙ МУНІЦИПАЛЬНИЙ АКАДЕМІЧНИЙ ТЕАТР ОПЕРИ І БАЛЕТУ ДЛЯ ДІТЕЙ ТА ЮНАЦТВА У ДЗЕРКАЛІ ОКРЕМИХ ПЕРСОНАЛІЙ
}

\author{
Ділявер Османов ${ }^{1 a}$, Микола Артюшенко ${ }^{2 a}$, Дар'я Миколенко ${ }^{3 b}$ \\ ${ }^{1}$ заслужений діяч мистецтв України; e-mail: dilyaverosman@gmail.com; ORCID: 0000-0001-7883-3828 \\ ${ }^{2}$ заслужений артист України; e-mail: mykolaartushenko@gmail.com; ORCID: 0000-0001-8946-3105 \\ ${ }^{3}$ e-mail: dariamykolenko@gmail.com; ORCID: 0000-0001-9706-2280 \\ а Луганська державна академія культури і мистецтв, Київ, Україна

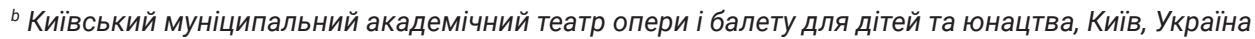

\section{Анотація}

У статті розглянуто шляхи творчих особистостей, які працювали в Київському муніципальному академічному театрі опери і балету для дітей та юнацтва, - солістки Людмили Монастирської, диригента Олексія Баклана, режисера Миколи Мерзлікіна, художника-сценографа Людмили Нагорної. Завдяки власним інтерв'ю з Л. Нагорною з'ясовано, що театр дає змогу отримати досвід сценічної практики та досвід діалогу «глядач - актор». На прикладі роботи режисера М. Мерзлікіна та художниці Л. Нагорної - представників художнього керівництва визначено, що правильно підібраний репертуар - успіх театру на довгі роки. Мета роботи проаналізувати діяльність КМАТОБ для дітей та юнацтва як платформу для реалізації творчих пошуків молодих митців сцени. Методологія полягає в системному використанні комплексних методів дослідження у вивченні творчої біографії особистостей, які працювали в Київському муніципальному академічному театрі опери і балету для дітей та юнацтва: аналітичного для опрацювання культурологічної, мистецтвознавчої та театрознавчої наукової літератури, також опрацювання архівних матеріалів; бібліографічного методу; методу наукового спостереження та аналізу; методу теоретичного узагальнення - для підбиття підсумків дослідження. Новизна дослідження. Мистецтвознавче дослідження діяльності Київського муніципального академічного театру опери і балету для дітей та юнацтва на прикладі вивчення творчості Людмили Монастирської, Олексія Баклана, Миколи Мерзлікіна, Людмили Нагорної сприяло виявленню специфіки роботи колективу як платформи для реалізації творчих пошуків молодих митців сцени. Висновки. Обґрунтовано важливе значення створення театру як осередку виховання та розвитку молодого покоління не тільки митців, а й глядача. Театр сприяє розкриттю талантів молодих виконавців і постановників; надає змогу для експериментів як у постановочній, так і виконавській царині сценічного мистецтва, зокрема оперно-балетного; прищеплюючи в юних глядачів музичну культуру, сприяє розвитку діалогу «глядач - актор».

Ключові слова: Київський муніципальний академічний театр опери і балету для дітей та юнацтва; Л. Монастирська; співачка; О. Баклан; диригент; М. Мерзлікін; режисер; Л. Нагорна; художник-сценограф 


\section{Постановка проблеми}

На сьогодні видається актуальною проблема вивчення особистості діяча культури. Одним з основних традиційних жанрів є біографія, в якій простежується «розвиток неповторної людської особистості, розкриття її внутрішнього світу в тісному взаємозв'язку з епохою і справою, якій ця особистість себе присвятила» (Павлова, 1990, с.8). Залежно від ставлення автора до подання матеріалубіографії і до особистості свого героя всі біографії умовно поділяють на чотири типи: наукові, науково-популярні, науково-художні та романізовані. Нас цікавить науково-популярна біографія. Тут історична особистість має значення й зацікавлює не сама собою, а залежно від тієї ролі, яку вона грала в конкретних подіях, який внесок зробила в культуру. Власне біографія, тобто життєвий шлях, психологічні особливості, моральні та духовні пошуки, деталі поведінки виявляються другорядними, іноді необов'язковими, якщо вони прямо не впливали на ті чи ті суспільно значущі події.

Безумовно, про діяльність кожного театру можна судити за його артистами. Вони продовжують традиції вокальної школи України, прославляючи її як у Вітчизні, так і за межами.

\section{Аналіз останніх досліджень і публікацій}

Роботи К. Власової, І. Драч, О. Зінькевич, Л. Нестеренко, О. Самойленко, В. Рожка, М. Черкашиної-Губаренко та ін. присвячені історико-культурним умовам розвитку музично-театрального мистецтва в Україні 80-90-х років XX початку XXI ст.; музикознавчі розвідки М. Бобрової, Г. Конькової, Л. Кияновської, В. Рожка, М. Черкашиної-Губаренко, Г. Черна та ін., в яких ідеться про специфіку музично-драматичних жанрів; періодичні видання (газети, журнали), в яких подано історію та виконавську діяльність Київського муніципального академічного театру опери і балету для дітей та юнацтва та його репертуарну політику.

Мета статті - проаналізувати діяльність КМАТОБ для дітей та юнацтва як платформу для реалізації творчих пошуків молодих митців сцени.

\section{Виклад основного матеріалу}

Державний дитячий музичний театр засновано в червні 1982 року. Засновниками театру стали відомі музиканти та діячі того часу. Директором новоствореного театру було призначено Івана Васильовича Дорошенка. На посаду головного диригента був призначений народний артист України Євген Васильович Дущенко, посаду головного хормейстера запропонували Михайлові Михайловичу Кречку. Першим головним балетмейстером театру став заслужений артист України Вадим Федотов, першим головним художником призначено Олександра Бурліна. Ці видатні майстри зробили дуже вагомий внесок у формування та становлення нового театрального колективу. Уже після призначень ключових керівників театру почався тривалий процес підбору творчого складу нового колективу. Протягом двох років відбувалася підготовка до відкриття повноцінного 
Вісник Київського національного університету культури і мистецтв.

Серія: Сценічне мистецтво

театрального сезону. Прем'єрною виставою, якою відкривали Державний дитячий музичний театр, стала опера «Зима і весна» корифея українського музичного мистецтва Миколи Віталійовича Лисенка.

Театр успішно працює дотепер. За роки свого існування ця установа декілька разів міняла офіційні назви. Так у 2002 році на своє 20-річчя з нагоди ювілею йому було надано статус академічного. Від 2005 року театр змінює свою назву на Київський муніципальний академічний театр опери і балету для дітей та юнацтва (далі - КМАТОБ для дітей та юнацтва). А вже у 2019 році театр здійснив ребрендинг, замінив логотип та отримав нову лаконічну назву - Київська опера.

Київський муніципальний театр опери і балету для дітей та юнацтва від початку своєї роботи та дотепер є творчим майданчиком для талановитої молоді. Більшість солістів прийшли на роботу в театр одразу після завершення навчання в музичних і хореографічних закладах освіти. Наразі участь у постановках молодих за віком виконавців у поєднанні з їх високою професійністю сприяє виконанню багатьох постановочних завдань колективу. Адже у виставах театру, репертуар якого орієнтований переважно на дитячу та юнацьку аудиторію, часто присутні персонажі, виконання ролей яких може бути доручено виключно молодим артистам.

О. Москалець у статті «Недитяча доля дитячого театру» наголошує на винятковій місії діячів дитячих театрів і відповідальності митців перед суспільством за виховання молодої генерації глядачів:

«Працювати в такому театрі можуть тільки подвійно обдаровані люди. Дар артистичний має доповнюватися ще певною особливою жилкою, що дозволяє облишити амбіції в затаєне прагнення до великої сцени. Театр для дітей не терпить фальші, не підпускає до себе "коронованих" цинічних або грошолюбивих людей. Залишитися тут можуть лише беззавітно віддані отому самому “чистому мистецтву", про яке ми останнім часом, на жаль, звикли говорити хіба що з іронією». (Москалець, 2004)

На теренах театру перші кроки в професії робили відомі артисти, режисери, диригенти, художники та сценографи. Трупа театру складається з кращих представників музичного мистецтва. Цікаво, що завжди пріоритет віддають саме молодим виконавцям. За 39 років існування театру змінилося багато поколінь митців. Для багатьох талановитих виконавців театр став трампліном у світ кращих світових оперних театрів. Солістів-вокалістів зазвичай набирають (така практика наявна і сьогодні) одразу після закінчення вищих музичних закладів освіти. Цікаві творчі долі можна спостерігати на прикладі солістів театру. У цій статті наводимо інформацію про одних, на нашу думку, з найяскравіших митців, які в різні роки творчого життя театру працювали в КМАТОБ для дітей та юнацтва.

Найвідоміша українська оперна співачка сучасності, яка починала свій творчий шлях у КМАТОБ для дітей та юнацтва, народна артистка України, лауреат Національної премії ім. Т. Г. Шевченка, солістка Національної опери України Людмила Монастирська. Ії̈ майстерність і талант знані не тільки в нашій країні, а й за межами. Людмила Монастирська співає в найвідоміших театрах світу, таких як Метрополітен-опера, Ла Скала, Опера Бастилія тощо. В інтерв'ю мультимедійній платформі «Ukrinform» співачка зазначила: 
«В дитячому театрі своя специфіка роботи. Кого я тільки там не переграла! Але там ти не можеш собі дозволити десь недопрацювати, тому що в залі сидить маленький глядач, і якщо ти сфальшивиш, діти хоч і не "заблукають", але вони почнуть відволікатися, ховатися під крісла, і повернути їхню увагу буде дуже важко. Тож дитячий театр мене дуже багато чому навчив - це була свого роду путівка в життя і одна з важливих складових моєї творчої кар'єри». (Юрченко, 2015)

Ще одна постать, яка лишила дуже яскравий слід у творчому житті КМАТОБ для дітей та юнацтва, - це видатний диригент, народний артист України Олексій Баклан.

Диригент $€$ найвпливовішою фігурою в музичному театрі. Він передає всім виконавцям своє бачення та розуміння музичного образу, об'єднує їх своїм розумінням музичного твору. Під час виконання опери керує всім спектаклем диригент. Режисер не може втрутитися в хід спектаклю, а диригент, навпаки, може, тому що він не тільки керує оркестром, хором, балетом, співаками, щоб вони звучали злагоджено, а й усім, що відбувається на сцені. На плечах диригента лежить уся відповідальність за досконале втілення композиторського, режисерського та його власного задуму всієї оперної постановки.

у 1995 р. на посаду головного диригента призначили Олексія Баклана, учня уславленого Стефана Турчака. Прихід молодого маестро став новим творчим поштовхом у діяльності колективу. Оркестр театру гастролює за кордоном, бере участь у музичних фестивалях в найславетніших концертних залах світу. Олексій Федорович Баклан у 1995-2008 рр. був головним диригентом, а з 2008 по 2012 рр. - художнім керівником театру.

У Київському муніципальному академічному театрі опери і балету для дітей та юнацтва під орудою маестро було поставлено багато оперних і балетних вистав, а також концертних програм.

Як зазначено вище, співпраця диригента та режисера $є$ дуже тісною. Відмінність оперного режисера від драматичного обумовлена тим, що він працює над постановкою в нерозривному союзі з диригентом.

Одним з найвидатніших оперних режисерів, який працював у КМАТОБ для дітей та юнацтва, був народний артист України, лауреат Національної премії імені Тараса Шевченка Микола Мерзлікін (1936-2006).

3 постаттю цього майстра пов'язані одні з найкращих сторінок історії театру. у 1985 р. до Київського дитячого музичного театру прийшов видатний український митець Микола Іванович Мерзлікін, який до останнього подиху був його незмінним головним режисером. Окрім того, що вистави в постановці М. Мерзлікіна одразу ставали подією в житті не тільки міста, а й усієї країни, вони й досі живуть, а справу митця вже продовжують його учні та колеги.

Режисер багато в чому схожий з диригентом оркестру. По-перше, як диригент, він має подумки зібрати ідеал того, як має звучати музика, а режисер має в думках тримати картинку того, якою має бути вистава. По-друге, як і диригент, режисер має передавати своє бачення виконавцям, кожний з яких працює над створенням єдиного бачення. Що цікаво, Микола Іванович, працюючи з вокалістами, які нещодавно закінчили консерваторію, насамперед вимагав від них бути акторами. Адже опера - це театр, а не просто вокальне виконання. 3 кожним 
Вісник Київського національного університету культури і мистецтв.

Серія: Сценічне мистецтво

актором М. Мерзлікін працював із повною самовіддачею та вимагав від них такого ж ставлення.

Побутує думка, що режисура музичного театру - це щось другорядне, вона набагато простіша від режисури драматичної вистави або режисури кіно. М. Мерзлікін у своїх інтерв'ю це категорично заперечує: «На мій погляд, режисура - єдина. Якщо ти режисер, то мусиш вміти і кіно знімати, і оперу ставити, і драматичні вистави. Безперечно, усе має свою специфіку» (Конькова, 2001, с.27).

Специфіка музичного театру в тому, що основні ідеї диктує музика, а не текст, тому дуже важливо дібрати гідний музичний матеріал. А також під матеріал, під ролі підібрати гідний творчий склад солістів. Із цим завданням М. Мерзлікін завжди справлявся з успіхом. Зокрема режисер наголошував:

«Вистава вирішується сучасно, але в традиційно класичному плані. Проблеми, які порушує ця опера, - вічні... Хоча опера називається "Ріголетто", вважаю, що головних героїв тут троє і вони тісно пов'язані між собою. В основі вистави - й трагічні взаємини Герцога та Джільди, й взаємини батька та доньки, й залежність людини від обставин та оточення». (Чайковська упоряд., 2016, с.52)

Юрій Богдашевський писав про Миколу Івановича так: «Миколу Мерзлікіна не можна назвати "благополучним" режисером. Його шлях не устелений трояндами, хоча й вони були. Поряд із схвальними вигуками прибічників завжди лунали не менш гучні голоси противників. Часом ці суперечки набували занадто гострого характеру» (Чайковська упоряд., 2016, с.68). Однак М. Мерзлікін завжди критично ставився до своєї роботи, не звертаючи уваги на відгуки. Він робив те, що добре вмів і знав.

у 1985 р. майже одночасно з Миколою Мерзлікіним в Київському дитячому музичному театрі починає працювати обдарована випускниця Київського художнього інституту Людмила Нагорна, для якої вистава О. Костіна «Золоторогий олень» стала першою самостійною роботою.

Людмила Нагорна - заслужений художник України. Від 1985 - художникпостановник Київського муніципального академічного театру опери і балету для дітей та юнацтва, від 1992 - головний художник театру. Починала свою творчу діяльність і багато років працювала над створенням образів вистав саме в КМАТОБ для дітей та юнацтва. Як художник-постановник театру поставила на сцені понад 40 вистав і концертних програм.

Л. Нагорна в 1985 році закінчила Київський державний художній інститут (нині - Національна академія образотворчого мистецтва і архітектури), театральне відділення, під керівництвом народного художника України Д. Лідера. Звичайно кожен студент після закінчення закладу освіти хоче застосувати свої навички та знання на практиці. Одразу після закінчення закладу вищої освіти Людмила Нагорна спробувала свої сили в Дитячому музичному театрі (нині - Київський муніципальний академічний театр опери і балету для дітей та юнацтва). У цьому ж театрі дуже стрімко і почалася творча діяльність як художника-постановника одразу з масштабних вистав. Здебільшого вистави дублювалися з Московським державним академічним дитячим музичним театром ім. Н. І. Сац, за аналогією якого і створювався Київський дитячий музичний театр. Спочатку навіть виста- 
ви були такі ж самі, як у більш досвідченого побратима (наприклад, «Чарівна музика» М. Мінкова, «Зайчик-листоноша» І. Якушенка).

Вистави передусім призначені для дитячої аудиторії, які не дуже сприймали творчі цехи. Солістам-вокалістам хотілося співати більш серйозний музичний матеріал. У творах, які переносили з театру в театр, спостерігаємо більше розмовних і речитативних фрагментів.

Перші постановки Л. Нагорної - балет «Багряні вітрила» В. Юровського та, як зазначали раніше, опера-балет «Золоторогий олень» О. Костіна (режисер Микола Мерзлікін). Саме співпраця режисера М. Мерзлікіна та художника Л. Нагорної була цікавою і плідною. Художник-постановник у театрі - права рука режисера. Він не тільки втілює режисерський задум, а й разом з ним вигадує, якими художніми засобами передати ідею вистави, її настрій, атмосферу, тандем режисера та художника-сценографа шукає нові ходи, досі ніким не використані.

Вистава «Золоторогий олень» йшла успішно, Л. Нагорна втілила свій задум, незважаючи на невеликі технічні можливості, вона розробила підвісний місток, який неначе розташовувався в Карпатах, тканини символізували гори та вершини смерек, а в колодязі відображався промінь сонця. До речі, такий технічний принцип згодом використали в постановці вистави «Ніч перед Різдвом» М. Римського-Корсакова (режисер Л. Моспан-Шульга, диригент-постановник О. Баклан). Цього разу місток був уже вищий і розташований далі, углиб сцени. Саме ця вистава М. РимськогоКорсакова (за однойменною повістю М. Гоголя) стала улюбленою виставою художниці, прем'єра якої відбулася в Київському муніципальному академічному театрі опери ібалету для дітейтаюнацтва 27 лютого 2009 року. Постановка ввійшлав низку заходів, присвячених 200-річчю з дня народження Миколи Гоголя. Л. Нагорна створила на сцені театру поетичний образ українського села з традиційними різдвяними атрибутами: «сільські хатки, вкриті шапками снігу, небесні світила, що заспокійливо виблискують у темному небі, плетені з лози мости-візерунки, віконні рами, за якими Оксана чепуриться до колядок...» (Олтаржевська, 2009). Очевидці вистави звертали увагу на особливу красу, видовищність, колоритність, емоційну насиченість сценографічного рішення вистави. Головним елементом декораційного оформлення стала сплетена з лози конструкція (лозоплетіння - Т. Бабак), що гармонійно поєднувалася з масовими вокальними сценами (хормейстер-постановник, засл. працівник культури України А. Масленнікова) та доповнювалася чудовою музикою М. Римського-Корсакова з українськими народними інтонаціями, виразною грою акторів і незрівнянним гоголівським гумором (Велимчаниця, 2009).

У процесі підготовки вистави виникало багато проблем: для втілення замислу театр не має другої висоти, залаштункового простору та фінансового належного забезпечення. Усі ці «але» для художника-постановника, усі нерозв'язні проблеми не завадили успішній постановці вистави.

За роки існування цієї вистави в репертуарі театру змінилося багато акторських складів, однак «Ніч перед Різдвом» - одна з найпопулярніших вистав театру, на яку глядач ходив із задоволенням. Виконавці змінювалися, але вистава продовжувала радувати аудиторію. «Найголовніше в нашій роботі - придумати образ вистави і потім фантазувати на тему цього образу. Це доволі тонка робота, тому первісний задум обростає структурними елементами, перевтілюється 
Вісник Київського національного університету культури і мистецтв.

Серія: Сценічне мистецтво

в щось, іноді навіть протилежне, тим самим наповнюючи та розвиваючи виставу» (Конькова, 2001), - зазначає художниця Л. Нагорна.

Для дітей важлива кожна деталь, кожний фрагмент, вони не сприймають «театральних підробок та компромісів», сприймають театр як дійсність. Труднощі роботи саме в дитячому театрі полягають у зацікавленні юного глядача. Для дітей треба робити так само, як і для дорослих, і навіть краще. Безумовно ніхто не розділяє поняття «дитячий» і «недитячий»; усі декорації, костюми створюють по-справжньому, хоча для дитячої аудиторії є моральні заборони, певна цензура.

Особливо останнім часом у дітей присутнє так зване «кліпове» мислення. Дорослі в змозі концентрувати та тримати увагу довгий час, тримати подію, сприймати певний великий вокальний уривок. Юне покоління вже майже втратило це вміння, швидкість життя невгамовно зростає, як і зростає швидкість сприйняття побаченого чи почутого. Діти та підлітки звикли до кліпових моментів, до швидко змінюваних, подієвих мультфільмів, ігор. Неймовірно важко втримати дитячу увагу. Дослідниця українського театру та музикознавець Г. Конькова, аналізуючи сучасну глядацьку театральну аудиторію, наголошувала на її трансформаціях під впливом сучасних соціокультурних процесів:

«Змінилися темпи життя - вони прискорилися, а театр завжди вимагає людину немовби призупинитися, задуматися і стати співучасником театральної дії. Перед телевізором людина пасивна: ти можеш одночасно пити чай, малювати ескізи, думати про щось і при цьому виховувати дітей, в будь-який момент вийти з цієї "другої реальності", переключити канал... А коли глядач опиняється в театрі, він має стати співучасником тієї дії, яка відбувається на сцені, тобто він має працювати разом із художником, який пропонує йому мову саме таких костюмів та декорацій, з режисером, з композитором, диригентом, вокалістами, які саме сьогодні трактують цю виставу. Тому що сценографія - це, як зараз модно казати, перфоменс. Вся сценографія має бути доведена до стану мистецтва. Кожний фрагмент, навіть, здавалося, найнезначніший предмет має бути цікавим як на картині художника». (Конькова, 2001, с.43)

У наступній постановці опери «Король Дроздобород» (перше прочитання матеріалу; композитор Юрій Шевченко, режисер Дмитро Тодорюк) Людмила Нагорна використовує декорації, що часто змінюються та обертаються, за допомогою яких дія і режисерські рішення швидко змінюють одне одного.

Здається, опера - дуже складний вид мистецтва, а все одно не проходить без сліду для дітей. Перший головний диригент театру Є. Дущенко (1925-2011) говорив: «Пробудження в юної людини інтересу до музики, виховання у неї розуміння всіх тонкощів, всієї глибини музичного мистецтва - одна з основних задач колективу» (Шурова, 1985, с.137).

Творчий доробок Людмили Нагорної на сцені Київського муніципального академічного театру опери і балету для дітей та юнацтва чималий. Художниця здійснила постановки багатьох опер, балетів, мюзиклів, музично-драматичних вистав.

Новизна дослідження. Ураховуючи наведені вище факти з історії Київського муніципального академічного театру опери і балету для дітей та юнацтва, пов'язані з творчою діяльністю Людмили Монастирської, Олексія Баклана, Миколи Мерзлікіна, 
Bulletin of Kyiv National University of Culture and Arts.

Series in Stage Art

Людмили Нагорної, унаслідок їх аналітичного осмислення визначено особливості роботи колективу як платформи для реалізації творчих пошуків молодих митців сцени.

\section{Висновки}

Обґрунтовано важливе значення створення театру як осередку виховання та розвитку молодого покоління не тільки артистів, митців, але й глядача. Завдання театру - насамперед шукати молодих, талановитих, професійних, наповнених ідеями творчих особистостей. КМАТОБ для дітей та юнацтва від свого заснування вдало виконує основну місію - виховує в молоді почуття прекрасного, прищеплює культуру та любов до театру, зокрема оперно-балетного.

Виявлено також важливість для колективу дитячого театру опери та балету правильно підбирати музичний матеріал - не зважаючи на дитячу тематику та спрямованість на юного, часто непідготовленого глядача, він має бути високохудожнім. Особливість вистав, які ставлять саме в дитячому музичному театрі, полягає в тому, що вони мають бути пізнаваними, динамічними, яскравими, не затягнуті в часі, зрозумілими тощо.

У Київському муніципальному академічному театрі опери і балету для дітей та юнацтва глядач особливий, адже діти не сприймають фальші та надмірної метафоричності. Творчому вихованню дітей слід приділяти належну увагу, коли в маленької людини прокидається інтерес до прекрасного, до мистецтва, це потрібно підтримувати. Саме через залучення дітей до перегляду вистави та співучасті в ній можна виховати любов до мистецтва.

Розглянуто творчість видатних особистостей, які працювали в КМАТОБ для дітей та юнацтва і створювали вистави саме для цієї особливої авдиторії глядача - для дітей та юнацтва. Для відомої співачки Людмили Монастирської театр став свого роду путівкою в життя й одним з важливих складників її творчої кар'єри; для видатного диригента сучасності Олексія Баклана КМАТОБ став свого роду творчою платформою для втілення ідей і постановок вистав, які на сьогодні є візитівкою театру. На прикладі роботи представників художнього керівництва,зокрема режисера Миколи Мерзлікіна та художниці-сценографа Людмили Нагорної, визначено, що правильно підібраний репертуар - успіх театру на довгі роки. Саме режисер театру М. Мерзлікін, ставлячи вистави, робив усе, щоб вони відповідали всім критеріям театру для дітей та юнацтва. Сенс діяльності художника-сценографа Л. Нагорної, яка працювала в КМАТОБ для дітей та юнацтва, полягав у прагненні до ідеалу як абсолютної цінності та до фундаментальних цінностей людського буття.

Отже, проаналізувавши творчий шлях окремих персоналій в історичній ретроспективі театру, ми дійшли висновку, що театр часто $є$ точкою творчого відправлення та путівкою в життя для талановитої молоді, надає змогу для експериментів як у постановочній, так і виконавській царині сценічного мистецтва та сприяє розвитку діалогу «глядач - актор».

Театр для дітей та юнацтва як елемент культурного середовища функціонує в діалектичній єдності специфічної самоцінності мистецтва та соціально-культурних потреб суспільства в його бутті. Саме тому змістовні зміни в дитячому театрі $є$ своєрідним відображенням соціально-економічних процесів, що відбуваються в суспільстві. 


\section{СПИСОК ПОСИЛАНЬ}

Вебер, М., 1994. Рациональные и социологические основания социологии музыки. В: Избранное. Образ общества. Москва: Юрист.

Велимчаниця, О., 2009. Як на київських сценах Гоголя грають. Кіно-театр, 3, с.2-3.

Конькова, Г.В., 2001. Театр: вхід без квитків. В: Спрага музики: паралелі і час спогадів. Київ: Комбі-ЛТД. Кн. 1.

Москалець, О., 2004. Недитяча доля дитячого театру. ZN.UA. [online] Доступно: <https:// zn.ua/ukr/ART/nedityacha_dolya_dityachogo_teatru.html> [Дата звернення 02 березня 2021]. Олтаржевська, Л., 2009. «Ніч перед Різдвом» за мить до весни. Україна молода, 39.

Павлова, Т.А., 1990. Методологические проблемы. Биографистика в СССР. В: Историческая биография: сборник обзоров к XVII Международному конгрессу исторических наук (Мадрид, август 1990). Москва, с.8.

Чайковська, В. упоряд., 2016. Микола Мерзлікін: пошук досконалості. Київ: Видавничий дім «Києво-Могилянська академія».

Шурова, Н., 1985. Первый в республике. Советская музыка, 7, с.136-138.

Юрченко, Н., 2015. Людмила Монастирська, солістка Національної опери. Укрінформ. [online] Доступно: <https://www.ukrinform.ua/rubric-culture/1921735-lyudmila-monastirskasolistka-natsionalnoji-operi.html> [Дата звернення 02 березня 2021].

\section{REFERENCES}

Chaikovska, V. comp., 2016. Mykola Merzlikin: poshuk doskonalosti [Mykola Merzlikin: the search for perfection]. Kyiv: Kyiv-Mohyla Academy Publishing House.

lurchenko, N., 2015. Liudmyla Monastyrska, solistka Natsionalnoi opery [Lyudmila Monastyrska, soloist of the National Opera]. Ukrinform. [online] Available at: <https://www.ukrinform.ua/rubricculture/1921735-lyudmila-monastirska-solistka-natsionalnoji-operi.html>[Accessed2March2021]. Konkova, H.V., 2001. Teatr: vkhid bez kvytkiv [Theater: entrance without tickets]. In: Spraha muzyky: paraleli i chas spohadiv [Sprague music: parallels and hour of spogadiv]. Kyiv: Kombi-LTD. Book 1. Moskalets, O., 2004. Nedytiacha dolia dytiachoho teatru [Non-children's destiny of children's theater]. ZN.UA. [online] Available at: <https://zn.ua/ukr/ART/nedityacha_dolya_dityachogo_ teatru.html> [Accessed 2 March 2021].

Oltarzhevska, L., 2009. "Nich pered Rizdvom" za myt do vesny ["The night before Christmas" a moment before spring]. Ukraina moloda, 39.

Pavlova, T.A., 1990. Metodologicheskie problemy. Biografistika v SSSR [Methodological problems. Biography in the USSR]. In: Istoricheskaia biografiia: sbornik obzorov k XVII Mezhdunarodnomu kongressu istoricheskikh nauk (Madrid, Avgust 1990) [Historical biography: a collection of reviews to the XVII International Congress of Historical Sciences (Madrid, August 1990)]. Moscow, p.8.

Shurova, N., 1985. Pervyi v respublike [The first in the republic]. Sovetskaia muzyka, 7, pp.136-138. Veber, M., 1994. Ratcionalnye i sotciologicheskie osnovaniia sotciologii muzyki [Rational and Sociological Foundations of the Sociology of Music]. In: Izbrannoe. Obraz obshchestva [Selected. The Image of Society]. Moscow: lurist.

Velymchanytsia, O., 2009. Yak na kyivskykh stsenakh Hoholia hraiut [How Gogol is played on Kyiv stages]. Kino-teatr, 3, pp.2-3. 


\title{
КИЕВСКИЙ МУНИЦИПАЛЬНЫЙ АКАДЕМИЧЕСКИЙ ТЕАТР ОПЕРЫ И БАЛЕТА ДЛЯ ДЕТЕЙ И ЮНОШЕСТВА В ЗЕРКАЛЕ ОТДЕЛЬНЫХ ПЕРСОНАЛИЙ
}

\author{
Дилявер Османов ${ }^{1 a}$, Николай Артюшенкоa Дарья Миколенко $^{3 b}$ \\ ${ }^{1}$ заслуженный деятель искусств Украины; e-mail: dilyaverosman@gmail.com; ORCID: 0000-0001-7883-3828 \\ 2 заслуженный артист Украины; e-mail: mykolaartushenko@gmail.com; ORCID: 0000-0001-8946-3105 \\ ${ }^{3}$ e-mail: dariamykolenko@gmail.com; ORCID: 0000-0001-9706-2280 \\ а Луганская государственная академия культуры и искусств, Киев, Украина \\ ${ }^{\mathrm{b}}$ Киевский муниципальный академический театр оперы и балета для детей и юношества, Киев, Украина
}

\section{Аннотация}

В статье рассмотрены пути творческих личностей, которые работали в Киевском муниципальном академическом театре оперы и балета для детей и юношества, - солистки Людмилы Монастырской, дирижера Алексея Баклана, режиссера Николая Мерзликина, художника-сценографа Людмилы Нагорной. Благодаря собственным интервью с Л. Нагорной выяснено, что театр дает возможность получить опыт сценической практики и опыт диалога «зритель - актер». На примере работы режиссера М. Мерзликина и художницы Л. Нагорной - представителей художественного руководства - определено, что правильно подобранный репертуар - успех театра на долгие годы. Цель работы проанализировать деятельность КМАТОБ для детей и юношества как платформу для реализации творческих поисков молодых мастеров сцены. Методология заключается в системном использовании комплексных методов исследования в изучении творческой биографии личностей, которые работали в Киевском муниципальном академическом театре оперы и балета для детей и юношества: аналитического - для обработки культурологической, искусствоведческой и театроведческой научной литературы, также обработки архивных материалов; библиографического метода; метода научного наблюдения и анализа; метода теоретического обобщения - для подведения итогов исследования. Новизна исследования. Искусствоведческое исследование деятельности Киевского муниципального академического театра оперы и балета для детей и юношества на примере изучения творчества Людмилы Монастырской, Алексея Баклана, Николая Мерзликина, Людмилы Нагорной способствовало выявлению специфики работы коллектива как платформы для реализации творческих поисков молодых мастеров сцены. Выводы. Обосновано важное значение создания театра как центра воспитания и развития молодого поколения не только мастеров, но и зрителя. Театр способствует раскрытию талантов молодых исполнителей и постановщиков; дает возможность для экспериментов как в постановочной, так и исполнительской области сценического искусства, в частности оперно-балетного; прививая в юных зрителей музыкальную культуру, способствует развитию диалога «зритель - актер».

Ключевые слова: Киевский муниципальный академический театр оперы и балета для детей и юношества; Л. Монастырская; певица; А. Баклан; дирижер; Н. Мерзликин; режиссер; Л. Нагорная; художник-сценограф 


\title{
KYIV MUNICIPAL ACADEMIC OPERA AND BALLET THEATRE FOR CHILDREN AND YOUTH IN THE MIRROR OF INDIVIDUAL PERSONALITIES
}

\author{
Diliaver Osmanov ${ }^{1 a}$, Mykola Artiushenko ${ }^{2 a}$, Daria Mykolenko ${ }^{3 b}$ \\ ${ }^{1}$ Honored Artist of Ukraine; e-mail: dilyaverosman@gmail.com; ORCID: 0000-0001-7883-3828 \\ ${ }^{2}$ Honored Artist of Ukraine; e-mail: mykolaartushenko@gmail.com; ORCID: 0000-0001-8946-3105 \\ ${ }^{3}$ e-mail: dariamykolenko@gmail.com; ORCID: 0000-0001-9706-2280 \\ a Luhansk State Academy of Culture and Arts, Kyiv, Ukraine \\ ${ }^{b}$ Kyiv Municipal Academic Opera and Ballet Theatre for Children and Youth, Kyiv, Ukraine
}

\begin{abstract}
The article considers the ways of creative personalities who worked at the Kyiv Municipal Academic Opera and Ballet Theater for Children and Youth - soloist Liudmyly Monastyrska, conductor Oleksii Baklan, director Mykola Merzlikin, set designer Liudmyla Nahorna. Thanks to our own interviews with L. Nahorna, it was found out that the theater provides an opportunity to gain experience of stage practice and experience of dialogue "spectator - actor". On the example of the work of director M. Merzlikin and artist L. Nahorna - representatives of the artistic management it was determined that the right repertoire is a success of the theater for many years. The purpose of the article is to analyze the activity of KMATOB for children and youth as a platform for realization of creative searches of young artists of a scene. The methodology consists in the systematic use of complex research methods in the study of creative biographies of individuals who worked at the Kyiv Municipal Academic Opera and Ballet Theater for Children and Youth: analytical is for the study of cultural, art and theater scientific literature, as well as the processing of archival materials; bibliographic method; method of scientific observation and analysis; method of theoretical generalization is to summarize the study. The scientific novelty of the study. Art study of the Kyiv Municipal Academic Opera and Ballet Theater for Children and Youth on the example of studying the work of Liudmyla Monastyrska, Oleksii Baklan, Mykola Merzlikin, Liudmyla Nahorna helped to identify the specifics of the team work as a platform for the creative searches realization of young artists of the stage. Conclusions. The importance of creating a theater as a center of education and the young generation development of not only artists but also spectators has been substantiated. The theater helps to reveal the talents of young performers and directors; allows for experiments in both the staging and performing spheres of performing arts, in particular opera and ballet; instilling in young viewers a musical culture, promotes the dialogue development "viewer - actor".
\end{abstract}

Keywords: Kyiv Municipal Academic Opera and Ballet Theatre for Children and Youth; L. Monastyrska; a singer; O. Baklan; a conductor; M. Merzlikin; director; L. Nahorna; artist and scenographer 